\title{
Immunohistochemically confirmed HHV-8-related lymphoproliferative disorders in Uganda
}

\author{
Lynnette K Tumwine ${ }^{1,3}$, Robert Lukande ${ }^{1,3}$, Weiqiang Zhao ${ }^{2,3}$, Leona W Ayers ${ }^{2,3^{*}}$
}

From $12^{\text {th }}$ International Conference on Malignancies in AIDS and Other Acquired Immunodeficiencies (ICMAOI)

Bethesda, MD, USA. 26-27 April, 2010

\section{Background}

Human herpesvirus-8 (HHV-8) infection is endemic in Uganda and has an estimated 36\%-60\% seroprevalence. This virus is in the oropharynx and peripheral blood of Ugandans with Kaposi's sarcoma, and viremia is increased in those with HIV-1. While Kaposi's sarcoma is widely recognized as both endemic and with HIV epidemic, HHV-8 associated lymphoproliferative disorders have not been previously reported in Uganda. Evidence for these disorders was sought in lymphoma surveys conducted by sub-Saharan African Lymphoma Consortium (SSALC) consortium members in Uganda.

\section{Materials and methods}

Samples of 456 malignant lymphoma and adenopathy cases in formalin-fixed paraffin-embedded (FFPE) blocks from the Uganda SSALC and the Uganda AIDS and
Cancer Specimen Resource (ACSR) were examined for morphology and Lana-1 (immunohistochemical, IHC) for diagnosis of HHV-8 lymphoproliferative disorders. Samples were also tested (IHC and in situ hybridization, ISH) using 20 monoclonal antibodies for common NHL antigens, ISH for EBV-encoded RNA, and kappa/lambda light chains (ISH, Ventana, Tucson).

\section{Results}

Many but not all of reported HHV-8-related proliferative disorders were identified in this sample population. Those identified and remaining to be identified are listed in Table 1.

\section{Conclusions}

HHV-8 proliferative disorders excluding Kaposi's sarcoma are present but generally not recognized by

Table 1 Subtypes

\begin{tabular}{|c|c|c|c|}
\hline \multicolumn{3}{|l|}{ Subtype } & \multirow{2}{*}{$\frac{\mathbf{N}}{2}$} \\
\hline & Unicentric varieties & Hyaline vascular variant & \\
\hline \multirow[t]{3}{*}{ Castleman's disease } & Multicentric varieties & Plasma cell variant & 1 \\
\hline & & Plasmablastic variant & 1 \\
\hline & & Lymphocyte depleted & 1 \\
\hline \multicolumn{3}{|c|}{ Plasmablastic lymphoma (HHV-8 negative and positive) } & 2 \\
\hline \multicolumn{4}{|c|}{ Primary effusion lymphoma } \\
\hline \multicolumn{4}{|c|}{ Peripheral T-cell lymphoma } \\
\hline \multicolumn{4}{|c|}{ Diffuse large B-cell lymphoma } \\
\hline \multicolumn{3}{|c|}{ Plasmacytic lymphoproliferative disorder } & 1 \\
\hline \multicolumn{3}{|l|}{ Total } & 8 \\
\hline
\end{tabular}

*Correspondence: ayers.1@osu.edu

${ }^{2}$ Department of Pathology, The Ohio State University, Columbus, OH, USA

Full list of author information is available at the end of the article 
Ugandan clinicians and pathologists. Disorders are present in Uganda, especially in HIV-positive patients, in association with the high infection rates of both HIV-1 and HHV-8. Recognition is important because HHV-8 infection in HIV-1-positive patients associates with poor prognosis. Familiarity with the clinical presentation and tissue morphology of these disorders will likely result in recognition of the full range of reported HHV-8 proliferative complications. HHV-8-related lymphoma has increased prevalence in the HIV-1 infected. It arises and progresses in the face of highly active antiretroviral therapy immune reconstitution, making recognition of these disorders critical to patient care. We participate in the Sub-Saharan Africa Lymphoma Consortium [http:// www.ssalc.org] to expand the understanding of HIV/ AIDS-related malignancies and viral proliferative disorders in this region of the world.

\section{Acknowledgements}

This article has been published as part of Infectious Agents and Cancer Volume 5 Supplement 1, 2010: Proceedings of the $12^{\text {th }}$ International Conference on Malignancies in AIDS and Other Acquired Immunodeficiencies (ICMAOI). The full contents of the supplement are available online at http://www.biomedcentral.com/1750-9378/5?issue=S1.

\section{Author details}

${ }^{1}$ Department of Pathology, Makerere University, Kampala, Uganda.

${ }^{2}$ Department of Pathology, The Ohio State University, Columbus, OH, USA.

${ }^{3}$ Sub-Saharan Africa Lymphoma Consortium (SSALC/NCI).

Published: 11 October 2010
Submit your next manuscript to BioMed Central and take full advantage of:

- Convenient online submission

- Thorough peer review

- No space constraints or color figure charges

- Immediate publication on acceptance

- Inclusion in PubMed, CAS, Scopus and Google Scholar

- Research which is freely available for redistribution

Submit your manuscript at www.biomedcentral.com/submit 